\title{
Long-term variability of sea surface temperature in Taiwan Strait
}

\author{
Igor M. Belkin • Ming-An Lee
}

Received: 20 September 2013 / Accepted: 26 March 2014 / Published online: 15 April 2014

(C) The Author(s) 2014. This article is published with open access at Springerlink.com

\begin{abstract}
Long-term variability of sea surface temperature (SST) in the Taiwan Strait was studied from the U.K. Met Office Hadley Centre climatological data set HadISST1. In 19572011, three epochs were identified. The first epoch of cooling SST lasted through 1976. The regime shift of 1976-1977 led to an extremely rapid warming of $2.1^{\circ} \mathrm{C}$ in 22 years. Another regime shift occurred in $1998-1999$, resulting in a $1.0^{\circ} \mathrm{C}$ cooling by 2011 . The cross-frontal gradient between the China Coastal Current and offshore Taiwan Strait waters has abruptly decreased in 1992 and remained low through 2011. The long-term warming of SST increased towards the East China Sea, where the SST warming in 1957-2011 was about three times that in the South China Sea. The long-term warming was strongly enhanced in winter, with the maximum warming of $3.8^{\circ} \mathrm{C}$ in February. The wintertime amplification of long-term warming has resulted in a decrease of the north-south SST range from 5 to $4{ }^{\circ} \mathrm{C}$ and a decrease in the amplitude of seasonal cycle of SST from 11 to $8^{\circ} \mathrm{C}$.
\end{abstract}

\section{Introduction}

The Taiwan Strait is one of the world's most important passages. Oceanographically, it connects two major marginal seas, the East China Sea (ECS) and South China Sea (SCS) (Fig. 1, top). Biogeographically, it's a migration route for many fish species (Chang et al. 2013). Economically, it's one of the busiest sea lanes, with 58,279 cargo vessels crossing the Strait in 2012 (MOTS 2013), and home to captive marine fishing grounds and mariculture

Electronic supplementary material The online version of this article (doi:10.1007/s10584-014-1121-4) contains supplementary material, which is available to authorized users.

I. M. Belkin

Graduate School of Oceanography, University of Rhode Island, 215 South Ferry Road, Narragansett, RI 02882, USA

e-mail: igormbelkin@gmail.com

M.-A. Lee

Department of Environmental Biology and Fishery Science, National Taiwan Ocean University, 2 Pei-Ning Road, Keelung 20224 Taiwan, Republic of China

M.-A. Lee $(\bowtie)$

Center of Excellence for Oceans, National Taiwan Ocean University, 2 Pei-Ning Road, Keelung 20224

Taiwan, Republic of China

e-mail: malee@mail.ntou.edu.tw 

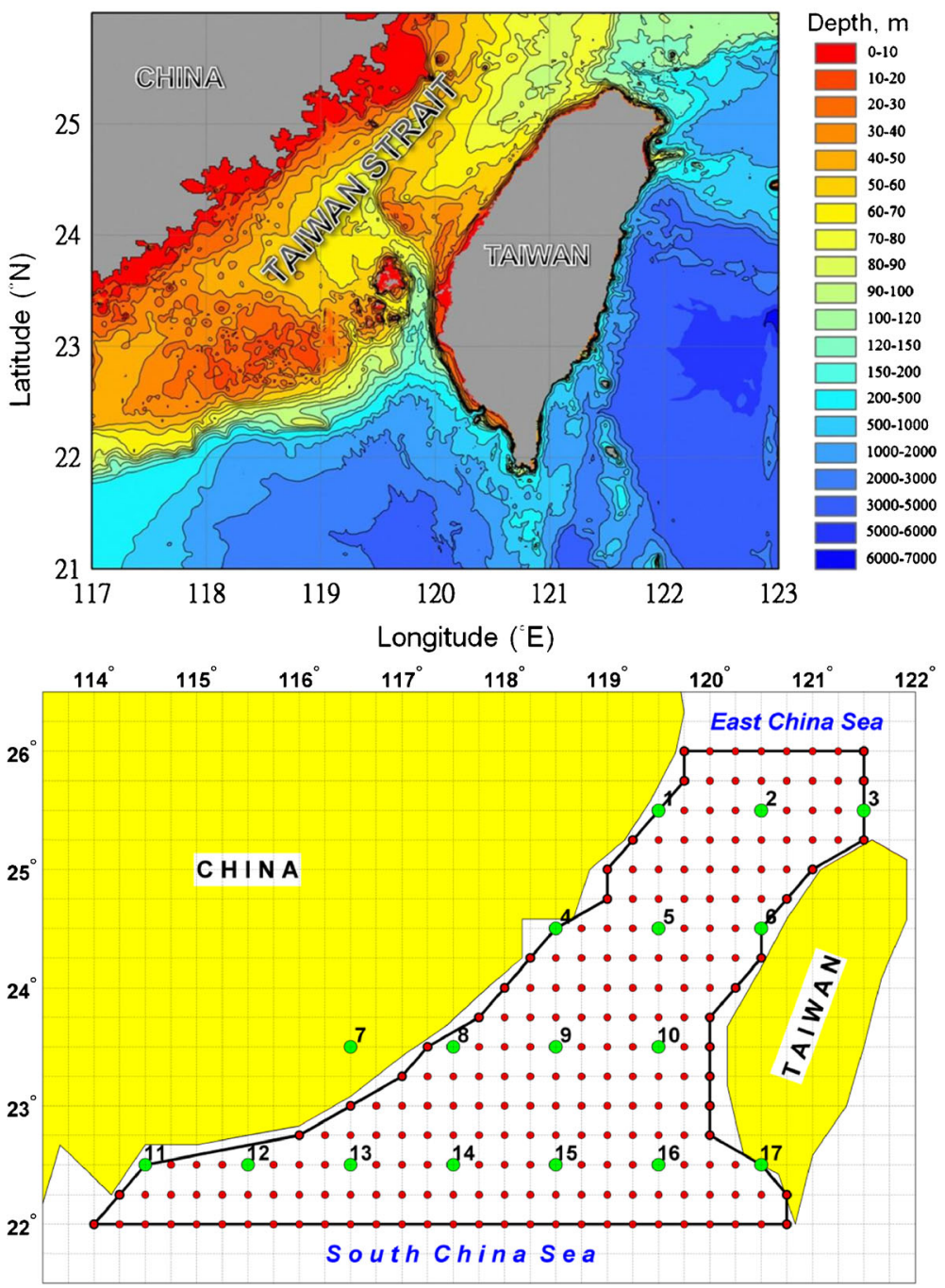

Fig. 1 (Top) Bathymetry of the Taiwan Strait. (Bottom) Base map of the Taiwan Strait region approximated by a polygon (black solid line) on a $0.25^{\circ} \times 0.25^{\circ}$ grid (small red dots). Hadley SST data are defined on a $1^{\circ} \times 1^{\circ}$ grid (large green circles with numbers) and interpolated onto the $0.25^{\circ} \times 0.25^{\circ}$ grid

(Chang et al. 2013). Demographically, 164 million people live on the shores of the Strait, including most of Taiwan's 23 million (http://en.wikipedia.org/wiki/Taiwan), and the entire Guangdong (104 million) and Fujian (37 million) provinces in China (http://en.wikipedia.org/ wiki/List_of_Chinese_administrative_divisions_by_population). Yet very few studies focused on the maritime climate of the Taiwan Strait (Kuo and Ho 2004; Kuo and Lee 2013; Oey et al. 2013).

The Taiwan Strait's climate is defined by the East Asia's land mass, being strongly affected by the Siberian High, especially in winter (Cohen et al. 2001). The Strait's seasonal variability is driven by the East Asian summer-winter monsoons (Zhang et al. 1997; Gong et al. 2001; Ding and Chan 2005). The seasonal switch in wind direction is amplified by the Strait's SW- 
NE orientation. The Strait's climate is sensitive to large-scale interannual variations originating in the Tropical Pacific (Wang et al. 2000; Kuo and Ho 2004). The Strait is a meeting place and a conduit of warm waters of the Kuroshio and SCS, and cold waters of the China Coastal Current (CCC) (Jan et al. 2002; Hong et al. 2011; Fig. S1 in online supplementary material), with a strong north-south gradient of sea surface temperature (SST), especially in winter (Fig. S2), when the Strait features the maximum north-south SST gradient in the entire western North Pacific (Jin and Wang 2011, Fig. 1a; see also Baumann and Doherty 2013).

The ECS Large Marine Ecosystem (LME) warmed rapidly in 1982-1998, whereas the adjacent SCS LME warmed much slower (Belkin 2009). The strong regional variability of global warming observed in the late 20th century across the East Asian seas begs a few questions: Which sea does the Taiwan Strait climate gravitate to, ECS or SCS? Has the Taiwan Strait warmed very fast (as ECS) or rather moderately (as SCS)? Has the late 20th century warming continued into the 21 st century?

The first modern studies of long-term SST variability in the China Seas were based on repeat oceanographic sections (Table 1). Lin et al. (2005) reported rapid warming in the Yellow Sea in 1976-2000. Ning et al. (2009) documented rapid warming of the South China Shelf in 1976-2004. Ning et al. (2011) found a significant warming in 1975-1995 in the Yellow Sea. Tang et al. (2009) found a relatively small warming $\left(\sim 0.5^{\circ} \mathrm{C}\right)$ between $1957-76$ and 1977-96 in the northern ECS. Wang et al. (2013) extended this data set through 2001 and analyzed a broader area of $23^{\circ}-41^{\circ} \mathrm{N}, 117^{\circ}-130^{\circ} \mathrm{E}$, where they found a significant warming after 1985 .

The above studies were based on in situ data. Meanwhile, inclusion of satellite SST made possible creation of global data bases that lend themselves to studies of global and regional climate change.

The U.K. Met Office Hadley Centre SST climatology HadISST1 has gained recognition in climate studies owing to its superior spatial $\left(1^{\circ} \times 1^{\circ}\right)$ and temporal (monthly) resolution and time span that goes back to 1870 (Rayner et al. 2003). The IPCC-2007 Report (Trenberth et al. 2007) was based on this data set. Alongside with global studies, the potential of Hadley climatology for regional climate assessments was realized early on (Sheppard and Rayner 2002; Sheppard 2004; Sheppard and Rioja-Nieto 2005). Belkin (2009) computed SST time series in 1957-2006 for 63 LMEs that has revealed an extremely rapid warming in the ECS, where SST rose by $2.5^{\circ} \mathrm{C}$ in 22 years, the fastest warming rate in the World Ocean. This study has also revealed strong regional variations in long-term trends of SST, which stimulated further applications of HadISST1 for regional climate assessments, particularly in the China Seas (Jin and Wang 2011; Liu and Zhang 2013).

The above works provide a strong incentive for using HadISST1 in regional climate assessments. Our goal is to document long-term variability of SST, study its spatial variations across the Taiwan Strait, and elucidate seasonality of the long-term variability. Figures S1 through S5 are found in Online Supplementary Material.

\section{Data and methods}

A global SST climatology HadISST1 compiled by the U.K. Met Office Hadley Centre consists of global fields with $1^{\circ} \times 1^{\circ}$ spatial resolution and monthly temporal resolution, from 1870 till present (Rayner et al. 2003). The present study uses the same methodology and data set as in Belkin (2009), updated through 2011.

There are only 17 one-degree cells that fall within the boundary of the Strait (Fig. 1, bottom). Nonetheless, this data set revealed a distinct spatial gradient of long-term trends of SST within the Strait. To study regional variations of such trends, monthly time series of SST 
Table 1 Long-term warming in the China Seas

\begin{tabular}{|c|c|c|c|c|c|c|}
\hline Authors & Region & Years & Seasons & Data & Parameter & $\begin{array}{l}\text { Warming } \\
\text { rate, }{ }^{\circ} \mathrm{C} / 10 \mathrm{a}\end{array}$ \\
\hline Lin et al. 2005 & YS: $36 \mathrm{~N}, 121-124.5 \mathrm{E}$ & $1976-2000$ & Annual & In situ & SST & 0.94 \\
\hline Lin et al. 2005 & YS: $36 \mathrm{~N}, 121-124.5 \mathrm{E}$ & $1976-2000$ & Winter & In situ & SST & 0.83 \\
\hline Lin et al. 2005 & YS: $36 \mathrm{~N}, 121-124.5 \mathrm{E}$ & $1976-2000$ & Summer & In situ & SST & 0.81 \\
\hline Lin et al. 2005 & YS: $36 \mathrm{~N}, 121-124.5 \mathrm{E}$ & $1976-2000$ & Annual & In situ & VAT & 0.68 \\
\hline Lin et al. 2005 & YS: $36 \mathrm{~N}, 121-124.5 \mathrm{E}$ & $1976-2000$ & Winter & In situ & VAT & 0.81 \\
\hline Lin et al. 2005 & YS: $36 \mathrm{~N}, 121-124.5 \mathrm{E}$ & $1976-2000$ & Summer & In situ & VAT & 0.56 \\
\hline Lin et al. 2005 & YS: $36 \mathrm{~N}, 121-124.5 \mathrm{E}$ & $1976-2000$ & Annual & In situ & BT & 0.38 \\
\hline Lin et al. 2005 & YS: $36 \mathrm{~N}, 121-124.5 \mathrm{E}$ & $1976-2000$ & Winter & In situ & BT & 0.67 \\
\hline Lin et al. 2005 & YS: $36 \mathrm{~N}, 121-124.5 \mathrm{E}$ & $1976-2000$ & Summer & In situ & BT & 0.48 \\
\hline Ning et al. 2009 & NSCS: SE of Hong Kong & 1976-2004 & Annual & In situ & SST & 0.78 \\
\hline Ning et al. 2009 & NSCS: SE of Hong Kong & 1976-2004 & Annual & In situ & VAT & 0.90 \\
\hline Tang et al. 2009 & ECS: $28-32 \mathrm{~N}, 122-128 \mathrm{E}$ & $1957-1996$ & Winter & In situ & SST & $0.12^{\mathrm{a}}$ \\
\hline Tang et al. 2009 & ECS: $28-32 \mathrm{~N}, 122-128 \mathrm{E}$ & $1957-1996$ & Summer & In situ & SST & $0.23^{\mathrm{a}}$ \\
\hline Ning et al. 2011 & ECS: $32 \mathrm{~N}, 122-127 \mathrm{E}$ & $1975-1995$ & Annual & In situ & SST & 0.34 \\
\hline Ning et al. 2011 & ECS: $32 \mathrm{~N}, 122-127 \mathrm{E}$ & $1975-1995$ & Annual & In situ & VAT & 0.45 \\
\hline Ning et al. 2011 & ECS: $32 \mathrm{~N}, 122-127 \mathrm{E}$ & $1975-1995$ & Annual & In situ & BT & 0.53 \\
\hline Xu et al. 2013 & ECS: $29-32 \mathrm{~N}, 122-123.5 \mathrm{E}$ & 1959-2009 & May & In situ & SST & $\sim 1.0^{\mathrm{b}}$ \\
\hline Wang et al. 2013 & $23-41 \mathrm{~N}, 117-130 \mathrm{E}$ & $1957-2001$ & Feb & In situ & SST & 0.67 \\
\hline Wang et al. 2013 & $23-41 \mathrm{~N}, 117-130 \mathrm{E}$ & $1957-2001$ & Aug & In situ & SST & 0.01 \\
\hline Wang et al. 2013 & $23-41 \mathrm{~N}, 117-130 \mathrm{E}$ & 1985-2001 & Feb & In situ & SST & 1.96 \\
\hline Wang et al. 2013 & $23-41 \mathrm{~N}, 117-130 \mathrm{E}$ & 1985-2001 & Aug & In situ & SST & 0.31 \\
\hline Belkin 2009 & ECS & $1982-2006$ & Annual & HadISST1 & SST & 0.5 \\
\hline Belkin 2009 & ECS & $1982-1998$ & Annual & HadISST1 & SST & 1.4 \\
\hline $\begin{array}{l}\text { Jin and Wang } \\
2011\end{array}$ & China Seas & $1870-2007$ & Annual & HadISST1 & SST & $\operatorname{Max}=0.12$ \\
\hline $\begin{array}{l}\text { Liu and Zhang } \\
2013\end{array}$ & $\begin{array}{l}\text { ECS and around } \\
\text { Taiwan }\end{array}$ & $1900-2006$ & Winter & HadISST1 & SST & 0.27 \\
\hline This study & Taiwan Strait & $1957-2011$ & Feb & HadISST1 & SST & $\operatorname{Max}=0.7^{\mathrm{c}}$ \\
\hline This study & Taiwan Strait & $1957-2011$ & Aug & HadISST1 & SST & $\operatorname{Max}=0.2^{\mathrm{c}}$ \\
\hline This study & Taiwan Strait & 1976-1998 & Annual & HadISST1 & SST & 1.0 \\
\hline
\end{tabular}

Acronyms: VAT vertically-averaged temperature; BT bottom temperature; YS Yellow Sea; ECS East China Sea; NSCS Northern South China Sea

${ }^{a}$ Tang et al. (2009) estimated an SST difference between the cold period of 1957-1976 and the warm period of 1976-1996. The decadal rates in this table are obtained from Tang et al.'s numbers given the 20-year separation between the center years of the cold (1966) and warm (1986) periods

${ }^{\mathrm{b}} \mathrm{Xu}$ et al. (2013) used data from 1959, 1981, and 1999-2009

${ }^{\mathrm{c}}$ Maximum rates in the Taiwan Strait; rates vary by factor of 3 across the Strait

were extracted for each $1^{\circ}$ node. Time series of annual SSTs were calculated from monthly SSTs for each $1^{\circ}$ node. Linear trends were estimated from time series of annual SSTs for each $1^{\circ}$ node.

To accurately estimate the area-mean SST trend in the Taiwan Strait, we approximated the Strait area by a polygon defined on a $0.25^{\circ} \times 0.25^{\circ}$ grid between 22 and $26^{\circ} \mathrm{N}$ (Fig. 1, bottom) and interpolated SST onto this grid. The $0.25^{\circ} \times 0.25^{\circ}$ gridded data were used to calculate area- 
weighted Strait-wide mean monthly SST for each individual month, 01/1957-12/2011. The individual mean monthly SSTs were averaged over 1957-2011 for each month to produce long-term mean monthly SSTs. The same individual mean monthly SSTs were averaged for each year to produce mean annual SSTs for the entire Taiwan Strait and estimate long-term trend for this area in 1957-2011. We only used data from 1957 on (as in Belkin 2009) since data density has sharply increased in 1957 thanks to the International Geophysical Year 1957-1958.

\section{Results}

The time series of area-mean annual SST revealed three epochs and two regime shifts (Fig. 2, top), the latter coincident with large-scale events, a trans-Pacific regime shift in 1976-1977 (Hare and Mantua, 2000) and the 1997-1998 El Niño (McPhaden 1999). The SST warming rate varies three-fold along the Taiwan Strait, from $0.7^{\circ} \mathrm{C}$ off Hong Kong up to $2.1^{\circ} \mathrm{C}$ east of Kinmen (Fig. 2, bottom).

The north-south SST gradient along the Strait decreased from $5{ }^{\circ} \mathrm{C}$ in 1957 to $4{ }^{\circ} \mathrm{C}$ in 2011 as the colder northern Strait warmed much more than the warmer southern Strait (Fig. 2, bottom)(also see Lima and Wethey 2012; Baumann and Doherty 2013). The long-term warming of SST is seasonal: It is strongest in winter (January-March) and weakest in summer (July-September) (Figs. 3, 4 and 5). The maximum warming (SST 2011 minus SST $_{1957}$ ) calculated by linear regression of annual SST for each of 17 grid nodes peaked in February, reaching $3.8^{\circ} \mathrm{C}$ at node 4 (Fig. 4 , bottom). Long-term time series of monthly SST show the maximum warming rate reaching $1{ }^{\circ} \mathrm{C} /$ decade in wintertime. Indeed, the coldest winter SST was observed around 1968, when the average minimum winter SST dropped to nearly $16{ }^{\circ} \mathrm{C}$ (Fig. 5, top). By 1999, the average minimum winter SST reached $21{ }^{\circ} \mathrm{C}$, a $5{ }^{\circ} \mathrm{C}$ increase in 31 years (Fig. 5, top). The winter amplification of long-term SST warming has resulted in a substantial decrease in the amplitude of seasonal cycle of SST, from $11^{\circ} \mathrm{C}$ in $1960 \mathrm{~s}-1970$ s to $8^{\circ} \mathrm{C}$ in 2011 (Fig. 5, top). Time series of SST in 17 grid nodes, while synchronous across the Strait, reveal a major regime shift in 1992, when the SST gradient between nodes 7-8 and 910 has almost vanished (Fig. 4, top), suggesting a sharp weakening of a front between the China Coastal Current (CCC) and offshore waters (Belkin et al. 2009). The CCC front remained weak through 2011.

\section{Discussion}

\subsection{Comparisons with independent in situ data sets}

Our results are consistent with other regional studies based on independent in situ data (Table 1). In this respect, studies based on People's Republic of China (PRC) data are especially valuable because PRC data from ECS and Taiwan Strait are virtually absent in the World Ocean Database (WOD) maintained by the National Oceanographic Data Center (NODC/NOAA) (www.nodc.noaa.gov). Since the HadISST1 includes all available data from WOD, it means that PRC data from ECS and Taiwan Strait are largely absent in HadISST1 and therefore can be used for comparison. For example, Xu et al. (2013, Figs. 2-3) found a $2{ }^{\circ} \mathrm{C}$ warming between 1981 and 2001, which penetrated to the bottom (maximum depth, $60 \mathrm{~m}$ ) in the study area. The same conclusion (surface-to-bottom penetration of warming signal) is evident from Lin et al. (2005). Wang et al. (2013) documented a sharp increase in warming rate 


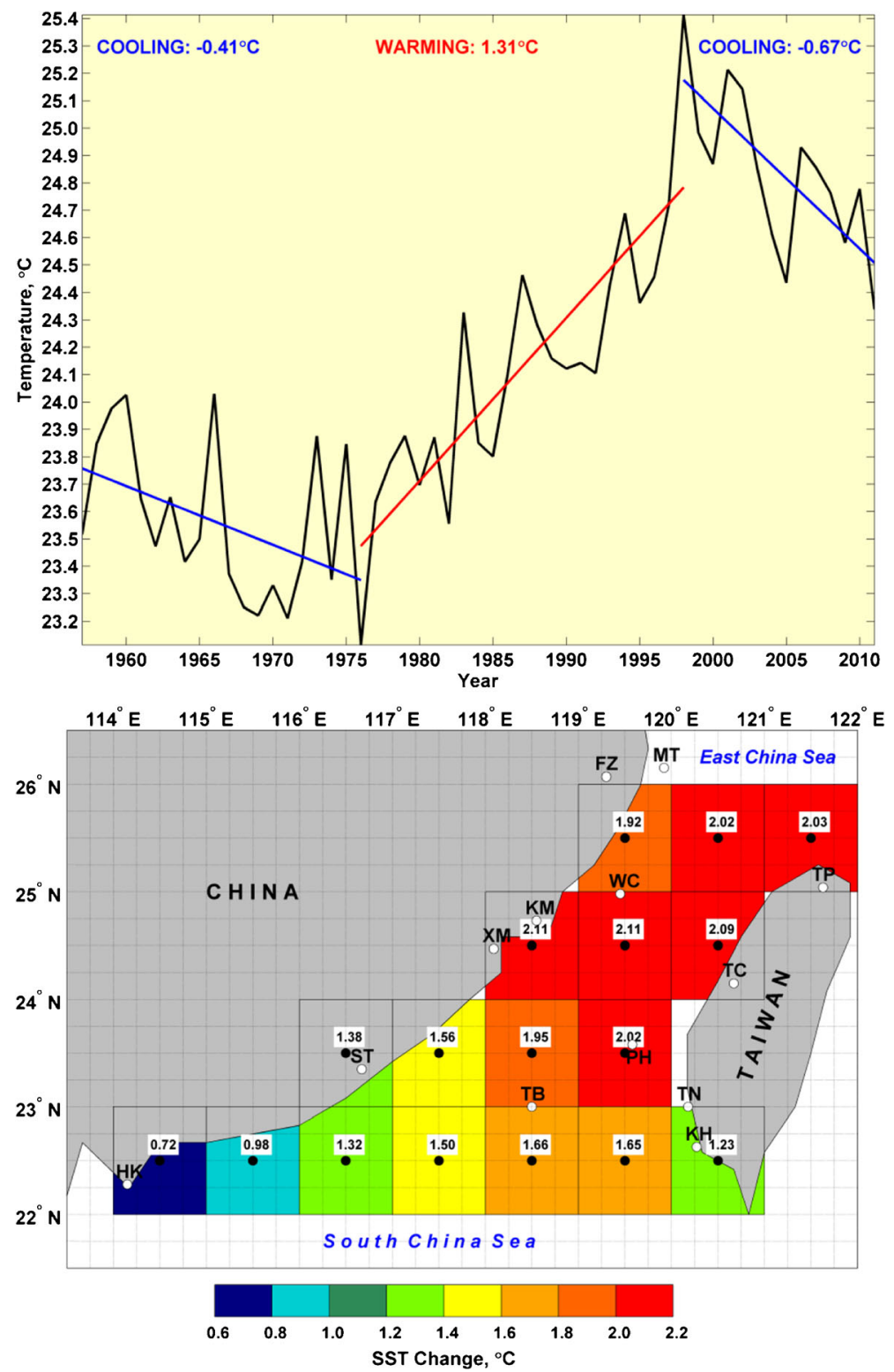

Fig. 2 (Top) Long-term variability of annual mean area-averaged SST in the Taiwan Strait region (bounded by a polygon in Fig. 4). Shown are three epochs: cooling in 1957-1976, warming in 1977-1998, and cooling in 19992011. (Bottom) Long-term SST trends in the Taiwan Strait. Shown are net SST changes $\left({ }^{\circ} \mathrm{C}\right)$ between 1957 and 2011 according to linear regression trends of annual data. The warming rates increase three-fold from the southwest $\left(0.7^{\circ} \mathrm{C}\right)$ to the northeast $\left(2.1^{\circ} \mathrm{C}\right)$. Acronyms: FZ, Fuzhou; HK, Hong Kong; KM, Kinmen; KH, Kaohsiung; MT, Matsu; ST, Shantou; TB, Taiwan Bank; TC, Taichung; TN, Tainan; TP, Taipei; PH, Penghu; WC, Wuchiu; XM, Xiamen

(up to $2{ }^{\circ} \mathrm{C} / 10 \mathrm{a}$ ) near the northern entrance to the Strait, especially in winter. These results are consistent with this study; they reinforce the usefulness of winter SST as a climate indicator representative of the entire upper mixed layer. 

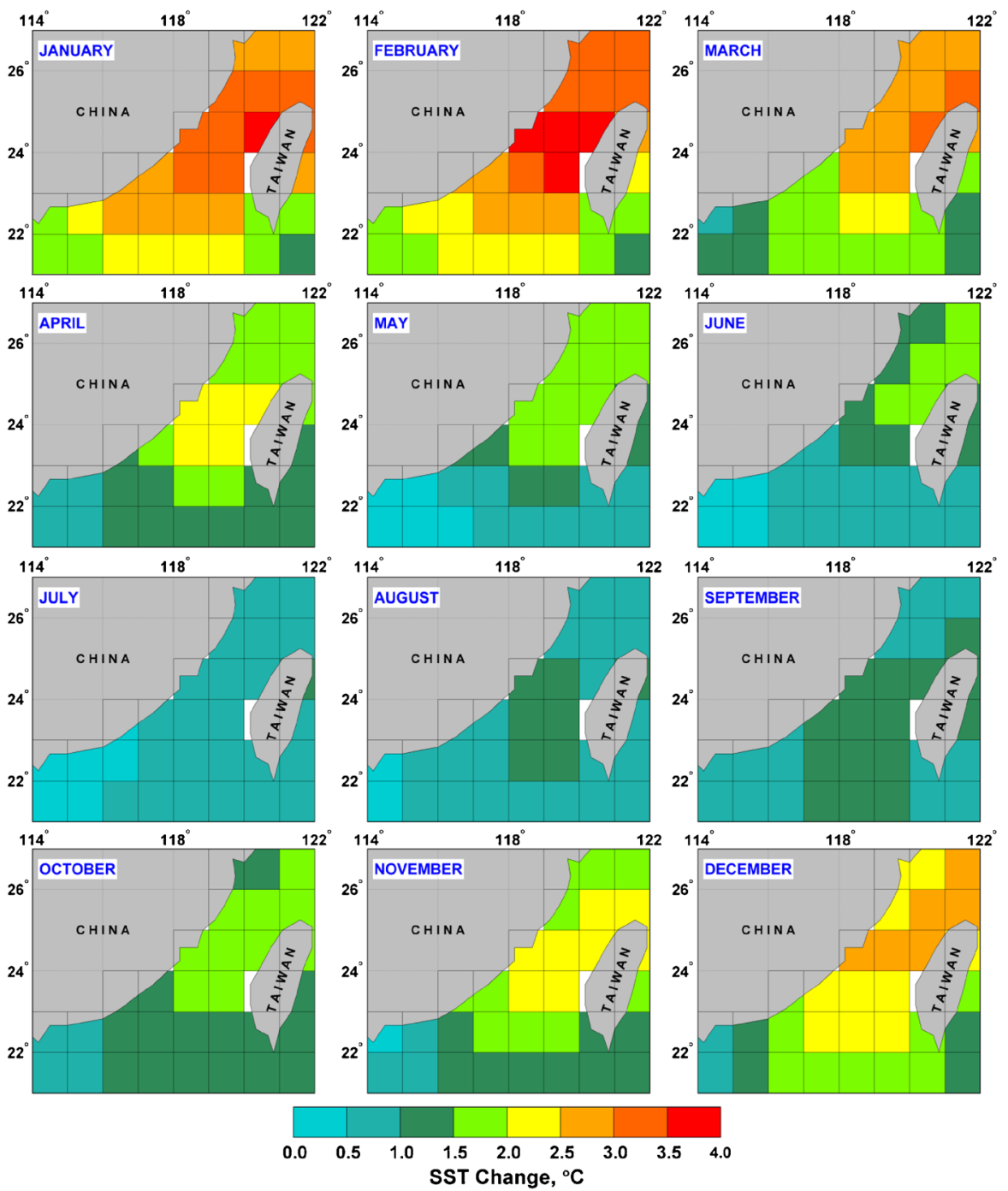

Fig. 3 Monthly maps of SST trends in the Taiwan Strait. Shown are net SST changes between 1957 and 2011 according to linear regression trends of monthly data

Coastal and offshore SST is routinely measured at fixed stations around Taiwan maintained by the Central Weather Bureau (CWB), Taipei (Fig. S3). The CWB has kindly made available to us this data. For this study we selected several stations in the eastern Taiwan Strait that have relatively long time span and no obvious instrumental problems or data gaps. Time series of SST at these stations (e.g., Fig. S4) reveal the post-1998 cooling consistent with the Strait-wide cooling in 1998-2011 (Fig. 2, top). A detailed analysis of the CWB data will be reported elsewhere.

\subsection{Validation of satellite-derived SST with in situ data}

Satellite SST data in waters around Taiwan were previously validated with in situ data (Lee et al. 2005, 2010). The AVHRR SST data were found to have a small bias of $<0.01{ }^{\circ} \mathrm{C}$ (Lee 

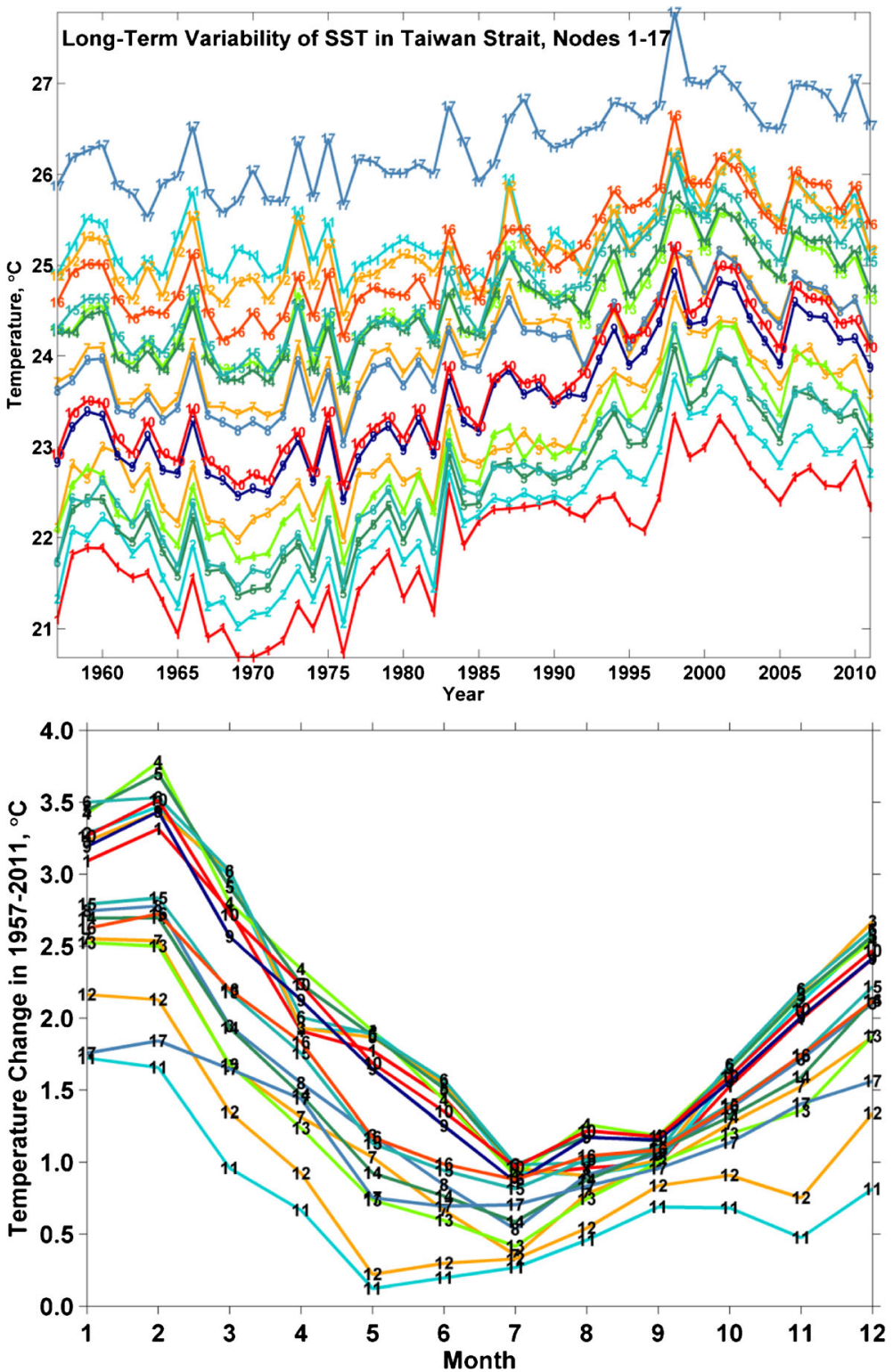

Fig. 4 (Top) Time series of SST in 17 nodes of Hadley $1^{\circ} \times 1^{\circ}$ grid in the Taiwan Strait, 1957-2011. The nodes are shown with large green circles in Fig. 4. During an abrupt regime change in 1992, the previously distinct SST gradient between nodes 7-8 (China Coastal Current) and 9-10 (offshore Taiwan Strait) has almost vanished. The entire zonal band (nodes 7-10) remained thermally uniform through 2011. (Bottom) Seasonal change of SST trends in 17 nodes of Hadley $1^{\circ} \times 1^{\circ}$ grid (large green circles in inset and in Fig. 4). The most rapid warming is observed in February along $24.5^{\circ} \mathrm{N}$ (nodes 4-6), with the maximum SST change in 1957-2011 exceeding $3.8^{\circ} \mathrm{C}$ (node 4)

et al. 2005). The MODIS Aqua and Terra SST data were found to have generally small biases, although larger than those of AVHRR SST (Lee et al. 2010). These biases, fortunately, are negligible relative to the rapid warming in 1976-1998, which occurred before Terra and Aqua 

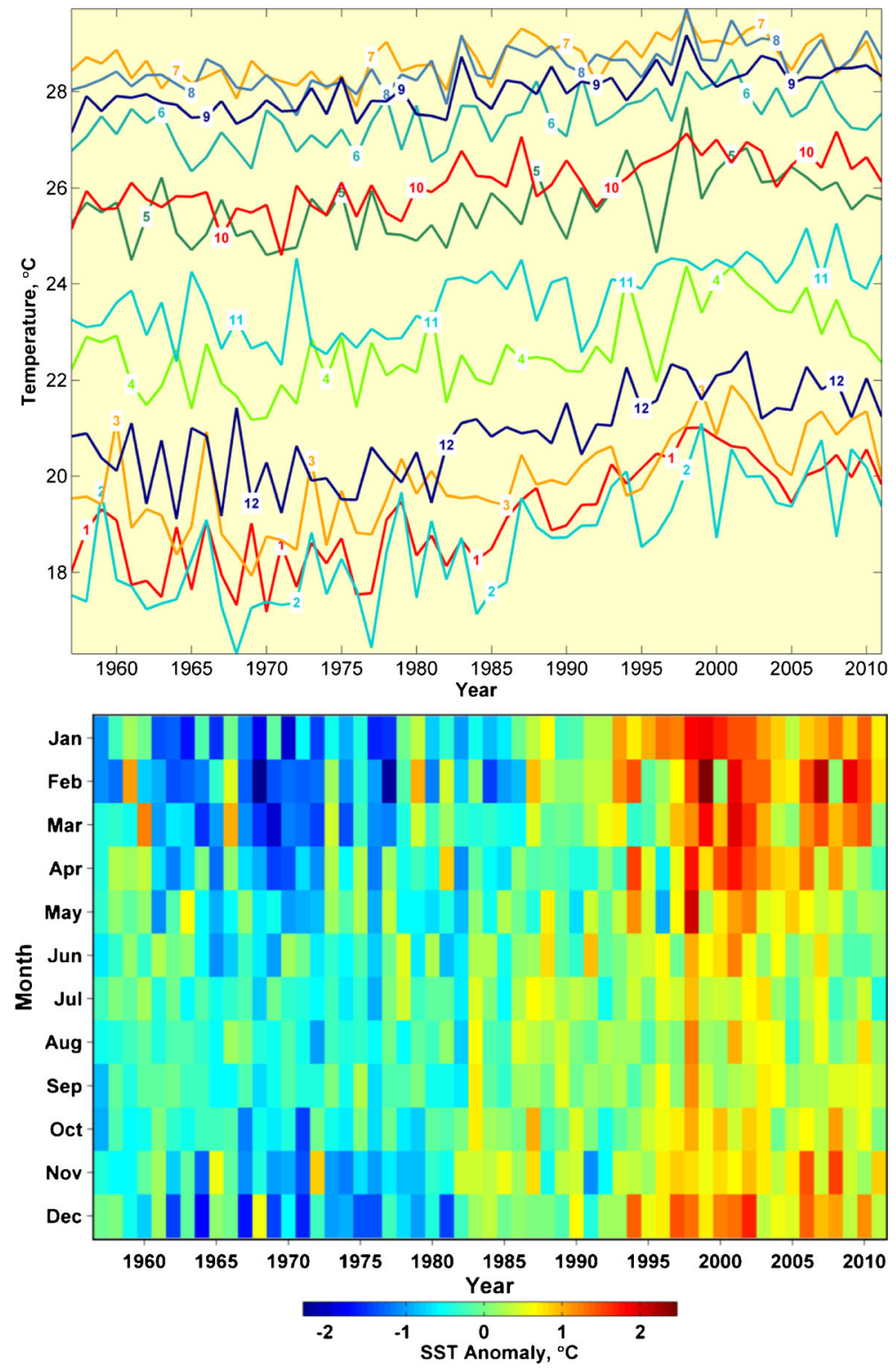

Fig. 5 (Top) Long-term variability of monthly SST in the Taiwan Strait. Numbers denote months (January, 1; February, 2; and so forth). (Bottom) Monthly area-averaged SST anomalies in the Taiwan Strait, 1957-2011. The anomalies have been calculated relative to the 1957-2011 means

have been launched. Even more important is the absence of any significant temporal drift in satellite-derived SST acquired from AVHRR and MODIS. A comparison of HadISST1 vs. HadSST2 (un-interpolated in situ data set) revealed a good agreement between the two (Rayner et al. 2006). 


\subsection{Comparison with Reynolds SST climatology}

The high-resolution $\left(0.25^{\circ}\right)$ daily satellite SST climatology by Reynolds et al. (2007) lends itself to comparison with our results. Lima and Wethey (2012) used this data set to study global coastal SST in 1982-2011. Our results compare favorably with those of Lima and Wethey (2012). Confirmed are (a) extremely rapid warming in ECS and Taiwan Strait; (b) southward decrease in warming rates toward SCS; (3) winter amplification of warming rates in a broad Taiwan Strait area. A close inspection of warming rates in Lima and Wethey (2012, supplementary data) reveals a discontinuity off the Yangtze Estuary, suggestive of a key role played by the Yangtze River discharge (Belkin 2009).

\subsection{Winter amplification of long-term SST warming}

The above-documented winter amplification of long-term SST warming can be explained by the seasonally-reversing, monsoon-driven circulation (Jan et al. 2002; Fig. S1). In winter, the regional circulation is dominated by the southward flow from ECS toward SCS. Since the ECS has been warming much faster than SCS, it explains the wintertime amplification of the longterm warming in the Taiwan Strait. Seasonality of SST warming in the China Seas has been studied by several researchers (Table 1). Mechanisms responsible for the enhanced winter warming in the western North Pacific were investigated by Yeh and Kim (2010), Heo et al. (2012) and Park et al. (2012). Clearly, the East Asian winter monsoon and its intensification (combined with the concomitant relaxation of the summer monsoon) play key roles. Even though predominant winter warming has been reported in most Northern Hemisphere coastal gradients (Baumann and Doherty 2013, Fig. 4), this phenomenon is exceptionally strong in the eastern China Seas (Lima and Wethey 2012, Figs. 3-8).

\subsection{China Coastal Current vs. Kuroshio}

Our results demonstrate that the Taiwan Strait is heavily influenced by ECS through the China Coastal Current and its offshore branches. Indeed, the warming rate of the Taiwan Strait is comparable with that of the ECS and much exceeds the warming rates of the Kuroshio and SCS (Belkin 2009). The crucial role of CCC in regulating the hydrography of the Taiwan Strait was amply demonstrated by the 2008 cold disaster caused by southward invasion of the CCC waters, when SST dropped by almost $8{ }^{\circ} \mathrm{C}$ vs. a 12-year mean February SST, causing substantial mortality of wild fish and a $80 \%$ loss of caged mariculture fish (Chang et al. 2009, 2013). The Kuroshio impact is limited by the southeastern part of the Strait, where in summer the SCS Warm Current flows northward alongside the Kuroshio branch (Jan et al. 2002; Fig. S1).

\subsection{Rapid warming in 1977-1998 and possible role of the Yangtze River discharge}

The extremely rapid warming of the ECS in 1976-1998 begs for explanation. Belkin (2009) suggested a key role of the Yangtze River outflow. Indeed, the Yangtze River and its tributaries act together to integrate terrestrial warming over a huge basin of $1,808,500 \mathrm{~km}^{2}$ and inject it into ECS. The annual discharge of up to $1,000 \mathrm{~km}^{3}$ (Yang et al. 2010) creates a buoyant plume that spreads across ECS. In summer, the plume is warmer than the ambient offshore water. The combined effect of low salinity and warm temperature results in the plume water's density being substantially less than that of the ambient water, thereby enhancing the plume's vertical stability and its 
capacity for trapping the incoming solar radiation. Thus, the Yangtze River runoff in summer should enhance surface warming. The above-described conceptual model of the Yangtze River discharge-driven enhancement of regional warming has been corroborated by Park et al. (2011).

Moreover, the Yangtze River outflow per se is an important seasonal heat source to ECS (Belkin 2009) since (a) the Yangtze discharge peaks in summer when riverine water is warmer than the ambient offshore water (Zhang et al. 2007), and (b) the Yangtze stream temperature in the estuary increased by $2{ }^{\circ} \mathrm{C}$ since the late 1960s (Fig. S5 after Zhou et al. 2005, Fig. 4), thereby enhancing the rapid warming east of the estuary (Ho et al. 2004; Belkin 2009, Fig. 4). The rapid increase of the Yangtze River stream temperature is consistent with the recent amelioration of winter climate in East Asia (e.g., Wang and Gong 2000), which is especially pronounced in the middle and lower reaches of the Yangtze River and in the Yangtze River Delta (e.g., Chen et al. 2006; Su et al. 2006). Another reason for a local maximum warming rate in the ECS is topographic trapping of the Yangtze discharge over the Yangtze Shoal, inside the Yangtze Shoal Ring Front (Belkin et al. 2009).

Among several factors that control the regional climate of the Taiwan Strait, the East Asian winter monsoon appears as one of the most important. Indeed, the recent amelioration of the North Pacific climate occurred thanks to a significant warming of the winter season, whereas the summer season temperatures remain fairly stable and even cooled slightly (Schneider and Held 2001; Thompson and Wallace 2001; Belkin et al. 2002). Particularly, the frequency of cold surges decreased dramatically between 1979-80 and 1994-95 (Zhang et al. 1997). These surges bring extremely cold and dry air from Central Asia, resulting in extreme heat loss by the sea to the atmosphere. The decrease in the total number of cold surges means higher winter SST in ECS and Taiwan Strait.

\subsection{Post-1998 cooling}

The global warming has slowed down after the global temperature peaked in 1998. Currently, the reasons for this sharp slowdown are not understood yet. In many regions around the world, the SST decreased after 1998 (Belkin 2009). Perhaps, nowhere was the post-1998 cooling as prominent as in the Taiwan Strait region, including ECS (Belkin, I.M., 2014. Rapid warming in Large Marine Ecosystems: An update through 2013, in preparation). Since the Taiwan Strait climate is strongly affected by the Siberian High, especially in winter, the Arctic is expected to be responsible for the post-1998 cooling. Outten and Esau (2012) suggested a link between the recent loss of the Arctic Ocean sea ice cover and the concurrent cooling trend over mid-latitude Eurasia. The loss of Arctic sea and extremely fast warming over Northern Eurasia and North-Western Canada, up to $5.8{ }^{\circ} \mathrm{C} / 10 \mathrm{a}$ in the Kara Sea, decrease the mean north-south temperature gradient, thereby weakening zonal winds and allowing cold Arctic air to escape south.

\section{Summary}

Multi-decadal variability of SST in the Taiwan Strait was studied from $1^{\circ} \times 1^{\circ}$ monthly climatology HadISST1. In 1957-2011, three epochs (regimes) were identified. The first epoch of cooling SST lasted through 1976. The regime shift of 1976-1977 led to a rapid warming of $2.1^{\circ} \mathrm{C}$ in 22 years. The regime shift of $1997-1998$ led to a $1.0^{\circ} \mathrm{C}$ cooling by 2011 . In the midst of the warming epoch, a sharp decrease of cross-frontal gradient between the China Coastal Current and offshore Taiwan Strait waters occurred in 1992-2011. The long-term net warming 
of SST in the Taiwan Strait increased three-fold from SCS to ECS and was pronounced in winter and weak in summer. The winter amplification of SST warming peaked along $24.5^{\circ} \mathrm{N}$, where February SST warmed in 1957-2011 at $>0.7^{\circ} \mathrm{C} /$ decade.

Acknowledgments This study was funded by the Republic of China's National Science Council (NSC). Visits by I.B. to the National Taiwan Ocean University (NTOU) were supported by NSC Grants Nos. 100-2621-M019-001, 101-2811-M-019-001, and 102-2811-M-019-002. The NSC support and NTOU hospitality are very much appreciated. The Central Weather Bureau in Taipei has kindly made available to us SST data measured at coastal and offshore stations. The long-term commitment of the U.K. Met Office Hadley Centre to assembling and maintaining a freely and easily available SST climatology is gratefully acknowledged. Bathymetry map (Fig. 1, top) is courtesy of Yi-Chun Kuo.

Open Access This article is distributed under the terms of the Creative Commons Attribution License which permits any use, distribution, and reproduction in any medium, provided the original author(s) and the source are credited.

\section{References}

Baumann H, Doherty O (2013) Decadal changes in the world's coastal latitudinal temperature gradients. PLoS ONE 8(6):e67596. doi:10.1371/journal.pone.0067596

Belkin IM (2009) Rapid warming of large marine ecosystems. Prog Oceanogr 81(1-4):207-213. doi:10.1016/j. pocean.2009.04.011

Belkin I, Krishfield R, Honjo S (2002) Decadal variability of the North Pacific Polar Front: Subsurface warming versus surface cooling. Geophys Res Lett 29(9). doi:10.1029/2001GL013806

Belkin IM, Cornillon PC, Sherman K (2009) Fronts in large marine ecosystems. Prog Oceanogr 81(1-4):223236. doi:10.1016/j.pocean.2009.04.015

Chang Y, Lee KT, Lee MA, Lan KW (2009) Satellite observation on the exceptional intrusion of cold water in the Taiwan Strait. Terr Atmos Ocean Sci 20(4):661-669. doi:10.3319/TAO.2008.08.07.01(Oc)

Chang Y, Lee MA, Lee KT, Shao KT (2013) Adaptation of fisheries and mariculture management to extreme oceanic environmental changes and climate variability in Taiwan. Mar Policy 38:476-482. doi:10.1016/j. marpol.2012.08.002

Chen LX, Li WL, Zhu WQ, Zhou XJ, Zhou ZJ, Liu HL (2006) Seasonal trends of climate change in the Yangtze Delta and its adjacent regions and their formation mechanisms. Meteorog Atmos Phys 92(1-2):11-23. doi: 10.1007/s00703-004-0102-y

Cohen J, Saito K, Entekhabi D (2001) The role of the Siberian high in Northern Hemisphere climate variability. Geophys Res Lett 28(2):299-302. doi:10.1029/2000GL011927

Ding YH, Chan JCL (2005) The East Asian summer monsoon: an overview. Meteorog Atmos Phys 89(1-4): 117-142. doi:10.1007/s00703-005-0125-Z

Gong DY, Wang SW, Zhu JH (2001) East Asian winter monsoon and Arctic Oscillation. Geophys Res Lett 28(10):2073-2076. doi:10.1029/2000GL012311

Hare SR, Mantua NJ (2000) Empirical evidence for North Pacific regime shifts in 1977 and 1989. Prog Oceanogr 47((2-4)):103-145. doi:10.1016/S0079-6611(00)00033-1

Heo KY, Ha KJ, Lee SS (2012) Warming of western North Pacific Ocean and energetics of transient eddy activity. Mon Weather Rev 140(9):2860-2873. doi:10.1175/MWR-D-11-00256.1

Ho CR, Lin CY, Huang SJ, Kuo NJ, Zheng Q (2004) Sea surface temperature variations in the China seas. In: Proceedings of the 13th Workshop of OMISAR (WOM-13) on Validation and Application of Satellite Data for Marine Resources Conservation, October 5-9, 2004, Bali, Indonesia, paper 02-05, http://sol.oc.ntu.edu. tw/omisar/wksp.mtg/WOM13/wom13.htm

Hong HS, Chai F, Zhang CY, Huang BQ, Jiang YW, Hu JY (2011) An overview of physical and biogeochemical processes and ecosystem dynamics in the Taiwan Strait. Cont Shelf Res 31(6):S3-S12. doi:10.1016/j.csr. 2011.02.002

Jan S, Wang J, Chern CS, Chao SY (2002) Seasonal variation of the circulation in the Taiwan Strait. J Mar Syst 35(3-4):249-268. doi:10.1016/S0924-7963(02)00130-6

Jin QH, Wang H (2011) Multitime scale variations of sea surface temperature in the China seas based on the HadISST dataset. Acta Oceanol Sin 30(4):14-23. doi:10.1007/s13131-011-0129-0 
Kuo NJ, Ho CR (2004) ENSO effect on the sea surface wind and sea surface temperature in the Taiwan Strait. Geophys Res Lett 31(13), L13309. doi:10.1029/2004GL020303

Kuo YC, Lee MA (2013) Decadal variation of wintertime sea surface temperature in the Taiwan Strait. J Mar Sci Technol Taiwan 21:117-123. doi:10.6119/JMST-013-1219-9

Lee MA, Chang Y, Sakaida F, Kawamura H, Cheng CH, Chan JW, Huang I (2005) Validation of satellite-derived sea surface temperatures for waters around Taiwan. Terr Atmos Ocean Sci 16(5):1189-1204

Lee MA, Tzeng MT, Hosoda K, Sakaida F, Kawamura H, Shieh WJ, Yang Y, Chang Y (2010) Validation of JAXA/MODIS sea surface temperature in water around Taiwan using the Terra and Aqua satellites. Terr Atmos Ocean Sci 21(4):727-736. doi:10.3319/TAO.2009.09.07.01(Oc)

Lima FP, Wethey DS (2012) Three decades of high-resolution coastal sea surface temperatures reveal more than warming. Nat Commun 3:704. doi:10.1038/ncomms1713

Lin C, Ning X, Su J, Lin Y, Xu B (2005) Environmental changes and the responses of the ecosystems of the Yellow Sea during 1976-2000. J Mar Syst 55((3-4)):223-234. doi:10.1016/j.jmarsys.2004.08.001

Liu QY, Zhang Q (2013) Analysis on long-term change of sea surface temperature in the China Seas. J Ocean Univ China 12(2):295-300. doi:10.1007/s11802-013-2172-2

McPhaden MJ (1999) Genesis and evolution of the 1997-98 El Niño. Science 283(5404):950-954. doi:10.1126/ science.283.5404.950

MOTS (Ministry of Transportation and Communication R.O.C.) (2013) Water Transport. http://www.motc.gov. tw/en/home.jsp?id=256\&parentpath $=0,150,250$

Ning X, Lin C, Hao Q, Liu C, Le F, Shi J (2009) Long term changes in the ecosystem in the northern South China Sea during 1976-2004. Biogeosciences 6(10):2227-2243

Ning X, Lin C, Su J, Liu C, Hao Q, Le F (2011) Long-term changes of dissolved oxygen, hypoxia, and the responses of the ecosystems in the East China Sea from 1975 to 1995. J Oceanogr 67((1)):59-75. doi:10. 1007/s10872-011-0006-7

Oey LY, Chang MC, Chang YL, Lin YC, Xu FH (2013) Decadal warming of coastal China Seas and coupling with winter monsoon and currents. Geophys Res Lett 40(23):6288-6292. doi:10.1002/2013GL058202

Outten SD, Esau I (2012) A link between Arctic sea ice and recent cooling trends over Eurasia. Clim Chang 110(3-4):1069-1075. doi:10.1007/s10584-011-0334-z

Park TW, Jang CJ, Jungclaus JH, Haak H, Park WS, Oh IS (2011) Effects of the Changjiang river discharge on sea surface warming in the Yellow and East China Seas in summer. Cont Shelf Res 31(1):15-22. doi:10. 1016/j.csr.2010.10.012

Park YH, Yoon JH, Youn YH, Vivier F (2012) Recent warming in the western North Pacific in relation to rapid changes in the atmospheric circulation of the Siberian high and Aleutian low systems. J Clim 25(10):34763493. doi:10.1175/2011JCLI4142.1

Rayner NA, Parker DE, Horton EB, Folland CK, Alexander LV, Rowell DP, Kent EC, Kaplan A (2003) Global analyses of sea surface temperature, sea ice, and night marine air temperature since the late nineteenth century. J Geophys Res 108(D14):4407. doi:10.1029/2002JD002670

Rayner NA, Brohan P, Parker DE, Folland CK, Kennedy JJ, Vanicek M, Ansell TJ, Tett SFB (2006) Improved analyses of changes and uncertainties in sea surface temperature measured in situ since the mid-nineteenth century: the HadSST2 dataset. J Clim 19(3):446-469. doi:10.1175/JCLI3637.1

Reynolds RW, Smith TM, Liu CY, Chelton DB, Casey KS, Schlax MG (2007) Daily high-resolution-blended analyses for sea surface temperature. J Clim 20(22):5473-5496. doi:10.1175/2007JCLI1824.1

Schneider T, Held I (2001) Discriminants of twentieth-century changes in Earth surface temperatures. J Clim 14(3):249-254. doi:10.1175/1520-0442(2001)014<0249:LDOTCC >2.0.CO;2

Sheppard C (2004) Sea surface temperature 1871-2099 in 14 cells around the United Kingdom. Mar Pollut Bull 49(1-2):12-16. doi:10.1016/j.marpolbul.2004.05.011

Sheppard C, Rayner NA (2002) Utility of the Hadley Centre sea ice and sea surface temperature data set (HadISST1) in two widely contrasting coral reef areas. Mar Pollut Bull 44(4):303-308. doi:10.1016/S0025326X(02)00059-0

Sheppard C, Rioja-Nieto R (2005) Sea surface temperature 1871-2099 in 38 cells in the Caribbean region. Mar Environ Res 60(3):389-396. doi:10.1016/j.marenvres.2004.12.006

Su BD, Jiang T, Jin WB (2006) Recent trends in observed temperature and precipitation extremes in the Yangtze River basin, China. Theor Appl Climatol 83(1-4):139-151. doi:10.1007/s00704-0050139-y

Tang XH, Wang F, Chen YL, Li MK (2009) Warming trend in northern East China Sea in recent four decades. Chin J Oceanol Limnol 27(2):185-191. doi:10.1007/s00343-009-9238-4

Thompson DWJ, Wallace JM (2001) Regional climate impacts of the Northern Hemisphere annular mode. Science 293(5527):85-89. doi:10.1126/science.1058958

Trenberth KE, Jones PD, Ambenje P, Bojariu R, Easterling D, Tank AK, Parker D, Rahimzadeh F, Renwick JA, Rusticucci M, Soden B, Zhai P (2007) Observations: surface and atmospheric climate change. In: Solomon 
S, Qin D, Manning M, Chen Z, Marquis M, Averyt KB, Tignor M, Miller HL (eds) Climate Change 2007: the Physical Science Basis. Contribution of Working Group I to the Fourth Assessment Report of the Intergovernmental Panel on Climate Change. Cambridge University Press, Cambridge, pp 235-336

Wang SW, Gong DY (2000) Enhancement of the warming trend in China. Geophys Res Lett 27(16):2581-2584. doi:10.1029/1999GL010825

Wang B, Wu RG, Fu XH (2000) Pacific-East Asian teleconnection: how does ENSO affect East Asian climate? J Clim 13(9):1517-1536. doi:10.1175/1520-0442(2000)013<1517:PEATHD>2.0.CO;2

Wang F, Meng QJ, Tang XH, Hu DX (2013) The long-term variability of sea surface temperature in the seas east of China in the past 40 a. Acta Oceanol Sin 32(3):48-53. doi:10.1007/s13131-013-0288-2

Xu ZL, Gao Q, Kang W, Zhou J (2013) Regional warming and decline in abundance of Euchaeta plana (Copepoda, Calanoida) in the nearshore waters of the East China Sea. J Crustac Biol 33(3):323-331. doi:10. $1163 / 1937240 X-00002140$

Yang SL, Liu Z, Dai SB, Gao ZX, Zhang J, Wang HJ, Luo XX, Wu CS, Zhang Z (2010) Temporal variations in water resources in the Yangtze River (Changjiang) over the Industrial Period based on reconstruction of missing monthly discharges. Water Resour Res 46, W10516. doi:10.1029/2009WR008589

Yeh SW, Kim CH (2010) Recent warming in the Yellow/East China Sea during winter and the associated atmospheric circulation. Cont Shelf Res 30(13):1428-1434. doi:10.1016/j.csr.2010.05.002

Zhang I, Sperber KR, Boyle JS (1997) Climatology and interannual variation of the East Asian winter monsoon: results from the 1979-95 NCEP/NCAR reanalysis. Mon Weather Rev 125(10):2605-2619. doi:10.1175/ 1520-0493(1997)125<2605:CAIVOT>2.0.CO;2

Zhang J, Liu SM, Ren JL, Wu Y, Zhang GL (2007) Nutrient gradients from the eutrophic Changjiang (Yangtze River) Estuary to the oligotrophic Kuroshio waters and re-evaluation of budgets for the East China Sea Shelf. Prog Oceanogr 74(4):449-478. doi:10.1016/j.pocean.2007.04.019

Zhou XY, Hu DB, Wang CZ, Hu XJ, Yao SK (2005) Seasonal and interannual SST variations in the Changjiang Estuary. Period Ocean Univ China 35(3):357-362, In Chinese, with English abstract and captions 